$$
\begin{aligned}
& \text { Sherly Jayantí \& Bayu Pratama Nugroho. Media Pembelajaran Cerita Tokoh Dalam Kitab } \\
& \text { Suci(Holy Bible) Untuk Anak Sekolah Minggu Menggunakan Macromedia Flash }
\end{aligned}
$$

\title{
MEDIA PEMBELAJARAN CERITA TOKOH DALAM KITAB SUCI (HOLY BIBLE) UNTUK ANAK SEKOLAH MINGGU MENGGUNAKAN MACROMEDIA FLASH
}

\author{
Sherly Jayanti, ST.,M.Cs', Bayu Pratama Nugroho, S.Kom., MT² \\ Prodi Manajemen Informatika Sekolah Tinggi Ilmu Manajemen Informatika dan Komputer (STMIK) \\ Palangkaraya JI. G. Obos No. I I4, kel. Menteng, Kec. Jekan Raya-73 I I 2 \\ Telp./Faks: (0536) 3224593, e-mail: humas@stmikplk.ac.id \\ Email : sherlyjayanti85@gmail.com
}

\begin{abstract}
The Covid-19 Pandemic period which began to spread since December 2019 is still being experienced until now, demanding that all activities or activities that could previously be done face-to-face or gathered in person can be done online, because it is considered capable of suppressing the rate of transmission of the COVID-19 virus. In this condition, Sunday school activities for children are also carried out online and are required to be able to present an interesting media in displaying singing, worshiping, telling stories, and physical movement activities. Therefore, it is necessary to create a Learning Media for Introduction to Characters from the Holy Bible (Holy Bible) for Sunday School Children by using the Macromedia Adobe Flash Professional CS6 application as a tool for making it. In making this media by following the right development method in its development, namely MDLC (Multimedia Development Life Cycle) by following six stages, namely, Concept, Design, Material Collecting, Assembly, Testing, and Distribution. So that media is produced that really helps children to know the stories of characters in the Bible, this media is equipped with references to verses from the Bible so that Sunday school children also know the books and verses that form the basis of the stories of the characters in the Bible. The Suci and there is also a Guess the Character Quiz with the aim of sharpening children's knowledge after reading the character's story.
\end{abstract}

Keywords : Up to six keywords should also be included.

\begin{abstract}
ABSTRAK
Masa Pendemi Covid-19 yang mulai menyebar sejak bulan desember tahun 2019 masih dialami sampai pada sekarang ini menuntut semua kegiatan atau aktivitas yang tadinya bisa dilakukan secara tatap muka atau berkumpul secara langsung menjadi bisa dilakukan secara daring (online), karena hal tersebut dianggap mampu menekan tingkat penularan dari virus covid-19. Dalam kondisi seperti ini kegiatan sekolah hari minggu untuk anak juga dilaksanakn secara daring dan dituntut agar bisa menyuguhkan sebuah media yang menarik dalam menampilkan kegiatan bernyanyi, menyembah, bercerita, dan aktivitas gerak fisik. Oleh karena itu dirasa perlu untuk membuat Media Pembelajaran Pengenalan Tokoh Cerita Kitab Suci (Holy Bible) untuk Anak Sekolah Minggu dengan memanfaatkan aplikasi Macromedia Adobe Flash Professional CS6 sebagai tools pembuatnnya. Dalam Pembuatan media ini dengan mengikuti metode pengembangan yang tepat dalam pengembangannya yaitu MDLC (Multimedia Development Life Cycle) dengan mengikuti enam tahapan yaitu, Concept, Design, Material Collecting, Assembly, Testing, dan Distribution. Sehingga dihasilkan Media yang sangat membantu anak-anak mengetahui Cerita Tokoh yang ada dalam Kitab Suci, Media ini dilengkapi dengan referensi ayat-ayat Kitab Suci agar anak-anak sekolah minggu juga mengetahui kitab dan ayat yang menjadi dasar dari cerita para tokoh-tokoh pada Kitab Suci tersebut dan juga ada Quiz Tebak Tokoh dengan tujuan mengasah pengetahuan anak setelah membaca cerita tokoh tadi.
\end{abstract}

\section{Kata kunci : Media, Pembelajaran, Tokoh, MDLC, Flash CS3, Kitab}

\section{PENDAHULUAN}

Masa Pendemi Covid-19 yang mulai menyebar sejak bulan desember tahun 2019 masih dialami sampai pada sekarang ini menuntut semua kegiatan atau aktivitas yang tadinya bisa dilakukan secara tatap muka atau berkumpul secara langsung menjadi bisa dilakukan secara daring (online), karena hal tersebut dianggap mampu menekan tingkat penularan dari virus covid-19. Kegiatan seperti belajar mengajar, transaksi berbelanja, layanan konsultasi dunia medis, transaksi bidang 


$$
\begin{array}{r|l}
\text { Jurnal Sains Komputer dan Teknologi Informasi } & \text { Page } \\
\text { e-issn: 2655-7460. Volume 4 No.1, November 2021 } & 56-65
\end{array}
$$

perbankan, bahkan dalam kegiatan beribadah pun dilakukan secara daring.

Mengingat sangat bergunanya media teknologi berupa gadget, smartphone atau tablet tersebut untuk anak-anak khususnya usia sekolah dasar maka sudah pasti untuk mengisi kegiatan kerohanian anak orang tua juga akan memastikan menggunaan media tadi untuk menyuguhkan informasi keagamaan seperti cerita tokoh Kitab Suci, situs sekolah minggu online, kegiatan bermain dan belajar tentang nilai-nilai keagamaan yang sesuai usia anak sekolah minggu.

Dalam menyuguhkan cerita kepada anak-anak sekolah minggu yang menjadi fokus dari penelitian ini, dikarenakan media yang bisa dinikmati atau digunakan oleh anak-anak usia sekolah minggu dirasa belum banyak yang menyediakan/ menyuguhkan dalam tampilan yang menarik minat membaca anak-anak, dan biasanya hanya satu tokoh saja yang diceritakan, serta tampilan belum interaktif sehingga anak-anak tidak terlalu berinteraksi dengan media yang ada.

Cara termudah untuk menuliskan makalah anda agar sesuai dengan format penulisan Jurnal adalah dengan men- copy-paste makalah anda ke dalam template ini. Template ini akan diberikan pada anda oleh redaksi Jurnal, bila makalah anda dinyatakan dapat diterbitkan di Jurnal, baik dengan revisi ataupun tidak. Penulisan istilah asing harus ditulis dalam huruf italics. Page setup untuk Jurnal adalah Top and Bottom $=2.54$ $\mathrm{cm}$, Left and Right $=3.17 \mathrm{~cm}$, Gutter $=0$ ". Orientasinya adalah Portrait dengan two columns (number of columns $=2$, dan col\# I dan 2 widht $=7.3 \mathrm{I} \mathrm{cm}$ dan spacing 0.63 $\mathrm{cm}$ ). Ukuran paper (paper size) adalah letter dengan Width $=21.59 \mathrm{~cm}$ dan Height $=27.94 \mathrm{~cm}$. Layout-nya dengan Header $=1.25 \mathrm{~cm}$ dan Footer $=1.54 \mathrm{~cm}$. Vertical alignment-nya adalah Top. (Catatan: Aturan penulisan desimal di atas disesuaikan dengan aturan penulisan pada Microsoft Word yang menggunakan ",." sebagai tanda desimal dan bukan ",". Aturan penulisan desimal dalam Jurnal mengikuti aturan penulisan Matematika).

\section{TINJAUAN PUSTAKA}

Pada penelitian ini mengambil dasar teori berdasarkan referensi sesuai dengan keperluan penelitian.

\section{I Media}

Menurut Musfiqon (2012:26) Media adalah perantara atau pengantar pesan dari pengirim ke penerima pesan. Pada hakekatnya kata media berasal dari bahasa Latin dan merupakan bentuk jamak dari kata medium yang secara harfiyah berarti perentara atau pengantar.

\subsection{Pembelajaran}

Hardini dan Puspitasari (2012:10). "Pembelajaran adalah suatu aktivitas yang dengan sengaja untuk memodifikasi berbagai kondisi yang diarahkan untuk tercapainya suatu tujuan, yaitu tercapainya tujuan kurikulum"

\subsection{Media Pembelajaran}

Menurut Arsyad (2016:4) media pembelajaran adalah komponen sumber belajar atau wahana fisik yang mengandung materi instruksional di lingkungan siswa yang dapat merangsang siswa untuk belajar.

Sudjana \& Rivai (2015:I) menyatakan bahwa media pembelajaran merupakan alat bantu mengajar yang ada dalam komponen metodologi, sebagai salah satu lingkungan belajar yang diatur oleh pengajar.

Peran media pembelajaran adalah menyediakan, menunjukkan, membimbing dan memotivasi pembelajar agar mereka dapat berinteraksi dengan berbagai sumber belajar yang ada. Bukan hanya sumber belajar yang berupa orang, melainkan juga sumber-sumber belajar yang lain. Bukan hanya sumber belajar yang sengaja dirancang untuk keperluan belajar, melainkan juga sumber belajar yang telah tersedia. Semua sumber belajar itu dapat kita temukan, kita pilih dan kita manfaatkan sebagai sumber belajar bagi pebelajar kita. Wujud interaksi antara pebelajar dengan sumber belajar dapat bermacam-macam.

\subsection{Cerita}

Menurut Kamus Besar Bahasa Indonesia (KBBI) Cerita adalah tuturan yang membentangkan bagaimana terjadinya suatu hal (peristiwa, kejadian, dan sebagainya) atau karangan yang menuturkan perbuatan, pengalaman, atau penderitaan orang, kejadian dan sebagainya (baik yang sungguh-sungguh terjadi maupun yang hanya rekaan belaka). Cerita juga adalah lakon yang diwujudkan atau dipertunjukkan dalam gambar hidup (sandiwara, wayang, dan sebagainya).

(https://kbbi.web.id/cerita)

\subsection{Tokoh}

Menurut Kamus Besar Bahasa Indonesia (KBBI) Tokoh merupakan rupa (wujud dan keadaan) dari orang yang terkemuka dan kenamaan (dalam bidang politik, kebudayaan, sejarah dan sebagainya) pemegang peran (peran utama) dalam roman atau drama. (https://kbbi.web.id/tokoh)

\subsection{Kitab Suci (Holy Bible) Indonesian Modern Bible Version}


Menurut Kamus Besar Bahasa Indonesia (KBBI), arti kitab suci adalah wahyu Tuhan yang dibukukan (seperti Al-Quran, injil, taurat, zabur). (https://kbbi.web.id/kitab)

YAKIN (Yayasan Anugerah Kebenaran Indonesia) telah menerbitkan kitab suci dalam terjemahan Indonesia, yang diterjemahkan langsung dari teks (Perjanjian Lama) Ibrani: Masoretic Text dan (Perjanjian Baru) Yunani: Textus Receptus. Kitab terbitan YAKIN ini diberi nama IMB (Indonesian Modern Bible), dengan terjemahan yang optimal, yaitu terjemahan dari teks aslinya, diterjemahkan ke dalam bahasa Indonesia, dengan bahasa yang enak dibaca dan mudah dimengerti tanpa mengurangi arti dan makna aslinya.

(https://www.yhschurch.com/resources/imb/)

\subsection{Model MDLC(Multimedia Development Life Cycle)}

Pengembangan metode multimedia ini dilakukan berdasarkan enam tahap, yaitu concept (pengonsepan), design (perancangan), material collecting (pengumpulan bahan), assembly (pembuatan), testing (pengujian), dan distribution (pendistribusian). Menurut Luther dalam Binanto, keenam tahap ini tidak harus berurutan dalam praktiknya, tahap-tahap tersebut dapat saling bertukar posisi. Meskipun begitu, tahap concept memang harus menjadi hal yang pertama kali dikerjakan. Gambar I yang adalah gambar tahapan metode MDLC.

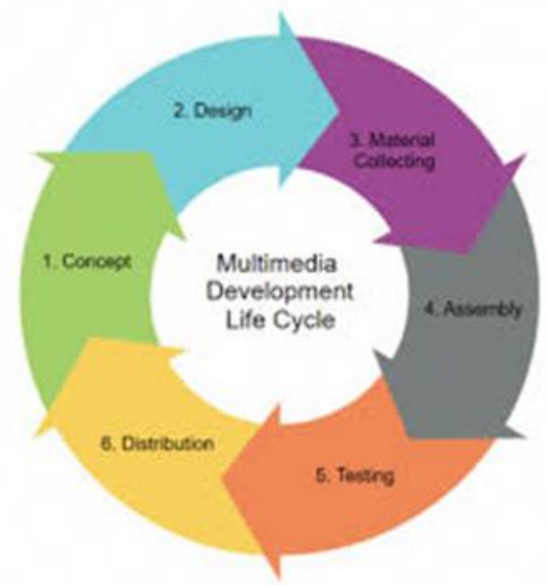

Gambar I. Enam Tahapan Metode MDLC

Sumber : Jurnal Online Informatika / Volume 2 No. 2 I p-ISSN: 2528-1682 / e-ISSN: 2527-9165

Adapun tahapan yang terdapat dalam metode pengembangan multimedia adalah sebagai berikut:

I. Tahap Konsep (concept)

2. Tahap Desain (design)

3. Tahap Pengumpulan Bahan (material collecting)

4. Tahap Pembuatan Objek atau Bahan (assembly)
5. Tahap Pengujian (testing)

6. Tahap Penyebaran (distribution)

\subsection{Adobe Flash Prfessional CS6}

Menurut Saputro (2016:2), flash adalah salah satu perangkat lunak yang sangat familiar dan mudah di operasikan. Bagi pengguna awam, Adobe Flash CS6 merupakan versi terbaru dari versi sebelumnya, Adobe Flash CS5. Program ini memiliki banyak fungsi, seperti pembuatan animasi objek, membuat presentasi, animasi iklan, game, pendukung animasi halaman web, hingga dapat digunakan untuk pembuatan film animasi.

Menurut Grover dalam Gautama dkk (2013:4), program Adobe flash adalah sebuah program animasi yang telah banyak digunakan oleh desainer untuk

\section{METODE PENELITIAN}

\section{I Metode Penelitian}

Model penelitian yang digunakan adalah metode Deskriptif kualitatif yaitu jenis penelitian yang bertujuan menafsirkan dan menguraikan data yang ada bersamaan dengan situasi yang sedang terjadi, serta mengungkapkan sikap, pertentangan, hubungan serta pandangan yang terjadi pada sebuah lingkup responden.

\subsection{Variabel Penelitian}

Variabel penelitian pada dasarnya adalah segala sesuatu yang berbentuk apa saja yang ditetapkan oleh peneliti untuk dipelajari sehingga diperoleh informasi tentang hal tersebut, lalu disimpulkan. Pada penelitian ini variabel yang diteliti berupa data materi tentang pengenalan tokoh yang ada pada Kitab Suci (Holybible) untuk Anak Sekolah Hari Minggu yang akan dipakai dalam media pembelajaran pengenalah tokoh berbasis multimedia.

\subsection{Pengumpulan Data}

Pada penelitian ini pengumpulan data-data sekunder yang diperlukan sesuai dengan kebutuhan dan perumusan masalah dilakukan dengan bebrapa teknik, yaitu:

I. Teknik Pengamatan

Tim peneliti akan mengamati kegiatan belajar mengajar pada gereja tempat anak-anak berkumpul mengikuti kegiatan sekolah minggu, kegiatan sekolah hari minggu yang dilaksanakan secara daring (online). $\mathrm{Hal}$ ini bertujuan untuk mengetahui materi yang disampaikan tentang pengenalan cerita tokoh-tokoh yang ada dalam Kitab Suci dalam kegiatan sekolah hari minggu.

2. Studi Literatur

Tim peneliti mencari literatur untuk mendapatkan informasi-informasi yang berhubungan dengan media 


$$
\begin{array}{r|l}
\text { Jurnal Sains Komputer dan Teknologi Informasi } & \text { Page } \\
\text { e-issn: 2655-7460. Volume 4 No.1, November 2021 } & 56-65
\end{array}
$$

dan materi pembelajaran tetang cerita tokoh atau pengenalan tokoh yang terdapat pada Kitab Suci melalui buku dan hasil penelitan dalam jurnal dan artikel sebelumnya.

Untuk pengumpulan data sekunder diperoleh dan dikumpulkan dengan melakukan studi pustaka mencakup buku-buku teks, jurnal, prosiding, artikel, diktat, makalah dan buku petunjuk teknis terpadu serta literature lain baik berupa cetak maupun daring.

\subsection{Model Pengembangan Sistem}

Penelitian ini menggunakan Metode Multimedia Development Life Cycle (MDLC) versi Luther-Sutopo dalam pengembangan/perancangannya. Menurut Sutopo, dalam Setiawan, dkk, yang berpendapat bahwa metode pengembangan multimedia terdiri dari enam tahapan, yaitu:

\section{Tahapan concept}

Tahap concept (konsep) adalah tahapan untuk menentukan tujuan dan siapa pengguna program (identifikasi audience). Selain itu menentukan macam aplikasi (presentasi, interaktif, dain lain-lain) dan tujuan aplikasi (hiburan, pelatihan, pembelajaran, dan lain-lain).

\section{Design}

Design (perancangan) adalah tahap membuat spesifikasi mengenai arsitektur program, gaya, tampilan dan kebutuhan material atau bahan untuk program. Yang digunakan pada tahapan ini adalah flowchart, yang disajikan pada Gambar 2.

Desain Storyboard digunakan untuk membuat outline atau visualisasi dari sebuah media. Storyboard yang digunakan untuk membuat konten media yang berbentuk form/tampilan.

\section{Material collecting}

Tahap pengumpulan bahan yang sesuai dengan kebutuhan yang dikerjakan. Bahan- bahan tersebut, antara lain gambar clip art, foto, animasi, audio dan lainlain yang dapat diperoleh secara gratis lewat internet sesuai dengan kebutuhan rancangannya

4. Assembly

Tahap assembly(pembuatan) adalah tahap dimana semua objek atau bahan multimedia dibuat. Pembuatan media didasarkan pada tahap design. Tahapan assembly ini meliputi, pembuatan marker, pembuatan konten motion, pembuatan background gambar 2D, dan pembuatan media. Pembuatan marker untuk konten 2D ini berbentuk silouete yang dibuat menggunakan Macromedia Adobe Flash CS6, menggunakan foto ikon tokoh, clip art atau gambar yang di dapat dari internet.

\section{Testing}

Tahap testing (pengujian) dilakukan setelah menyelesaikan tahap pembuatan (assembly) dengan menjalankan sistematau program dan melihat apakah ada kesalahan atau tidak. Pada pengujian fitur aplikasi, dan pengujian terhadap marker Pengujian fitur aplikasi ini merupakan pengujian terhadap fitur-fitur berupa tombol dan tampilan, apakah sudah berjalan sesuai yang diharapkan atau tidak.

6. Distribution

Pada tahap ini, sistem yang akan disimpan dalam suatu media penyimpanan jika media penyimpan tidak cukup untuk menampung aplikasinya, kompresi terhadap sistem tersebut akan dilakukan. Untuk sementara format penyimpanan dalam format file *swf (flash movie) yang akan bisa dijalankan pada flatform pemutar video atau pun pada Macromedia flash Player.

\section{HASIL DAN PEMBAHASAN}

Berdasarkan Langkah-langkah pengembangan Sistem yang digunakan maka dapat dilihat sebagai berikut hasil yang telah dikerjakan :

a. Tahapan concept

Tahap concept (konsep) adalah tahapan untuk menentukan tujuan dan siapa pengguna program (identifikasi audience). Selain itu menentukan macam aplikasi (presentasi, interaktif, dain lain-lain) dan tujuan aplikasi (hiburan, pelatihan, pembelajaran, dan lain-lain). Rincian konsep pada penelitian ini terdapat pada tabel I

\begin{tabular}{|c|c|}
\hline $\begin{array}{l}\text { Jenis } \\
\text { Multimedia }\end{array}$ & 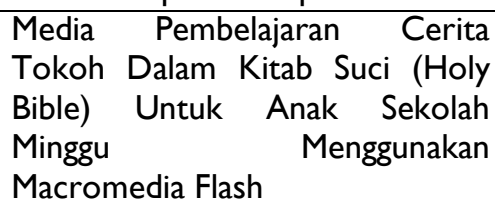 \\
\hline Tujuan & $\begin{array}{l}\text { Mengimplementasikan media } \\
\text { belajar berbasis multimedia pada } \\
\text { kegiatan Anak Sekolah Minggu } \\
\text { untuk memperkenalkan cerita } \\
\text { tokoh-tokoh yang ada dalam } \\
\text { Kitab Suci (Holy Bible). Dengan } \\
\text { harapan, anak-anak sekolah } \\
\text { minggu dapat memiliki gambaran } \\
\text { umum tentang kejadian yang } \\
\text { terjadi atau apa yang telah } \\
\text { dilakukan oleh tokoh-tokoh } \\
\text { dalam Kitab Suci tersebut. }\end{array}$ \\
\hline Sasaran & $\begin{array}{l}\text { Anak-anak yang mengikuti } \\
\text { kegiatan sekolah minggu. }\end{array}$ \\
\hline Audio & $\begin{array}{l}\text { Backsound dengan format audio } \\
\left({ }^{*} \text { wav }\right)\end{array}$ \\
\hline Gambar & Menggunakan gambar 2D \\
\hline
\end{tabular}

Tabel I. Deskripsi Konsep

\section{b. Design}

Design (perancangan) adalah tahap membuat spesifikasi mengenai arsitektur program, gaya, 
Sherly Jayantí \& Bayu Pratama Nugroho. Media Pembelajaran Cerita Tokoh Dalam Kitab

2021 Suci (Holy Bible) (Intuk Anak Sekolah Minggu Menggunakan Macromedia Flash

tampilan dan kebutuhan material atau bahan untuk program. Yang digunakan pada tahapan ini adalah flowchart, yang disajikan pada Gambar 2.

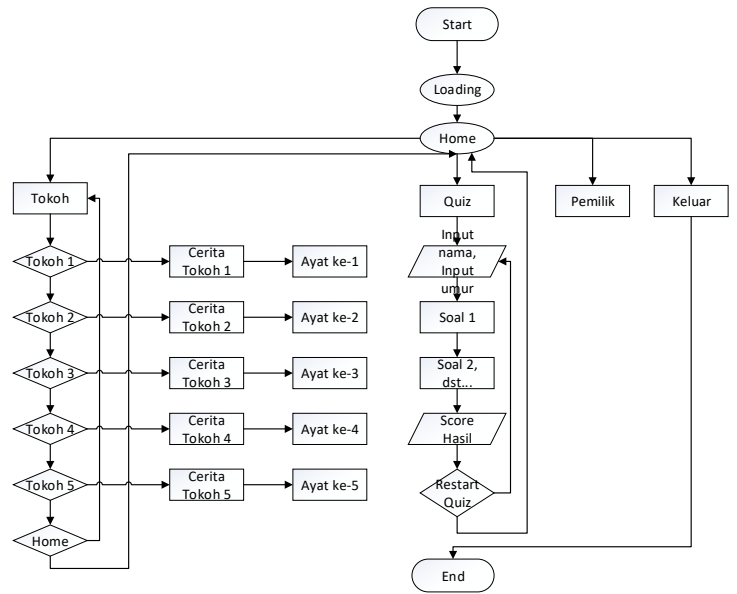

Gambar 2. Flowchart Media Pembelajaran

Desain Storyboard digunakan untuk membuat outline atau visualisasi dari sebuah media. Storyboard yang digunakan untuk membuat konten media yang berbentuk form/tampilan. Untuk tiap tampilan bisa dilihat berdasarkan gambar 3 sampai dengan gambar II.

\begin{tabular}{|l|c|c|l|l|}
\hline No. & $\begin{array}{c}\text { Nama } \\
\text { Layar }\end{array}$ & Aktivitas (Proses) & Sound & \multicolumn{1}{|c|}{ Link } \\
\hline 1. & $\begin{array}{l}\text { Tampilan } \\
\text { Loading }\end{array}$ & $\begin{array}{l}\text { Luara } \\
\text { pada saat } \\
\text { button } \\
\text { Home } \\
\text { muncul }\end{array}$ & $\begin{array}{l}\text { - Tombol ikon Home } \\
\text { (tampil layar Home) }\end{array}$ \\
& $\begin{array}{l}\text { Pada layar Loading } \\
\text { menampilkan button Home, } \\
\text { pada saat di klik akan berlanjut } \\
\text { ke tampilan layar Home. }\end{array}$ & \\
\hline
\end{tabular}

Gambar 3. Storyboard Tampilan Loading

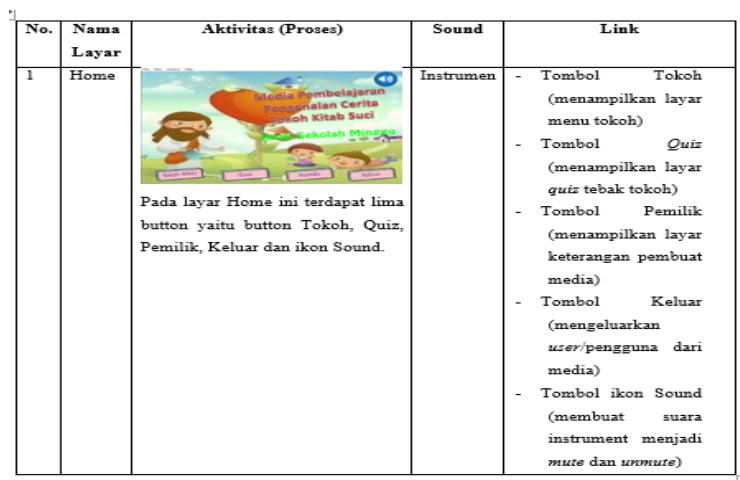

Gambar 4. Storyboard Tampilan Home

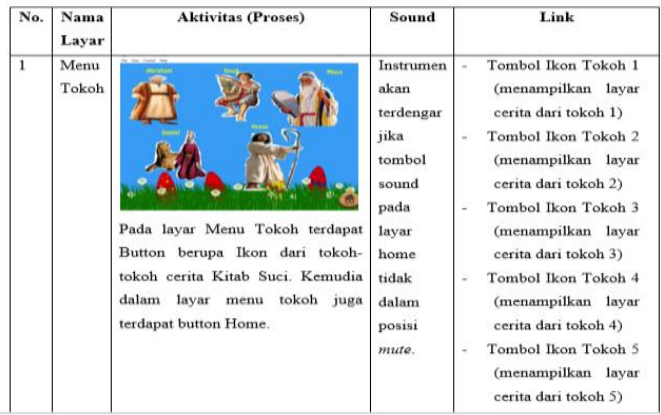

Gambar 5. Storyboard Tampilan Menu Tokoh

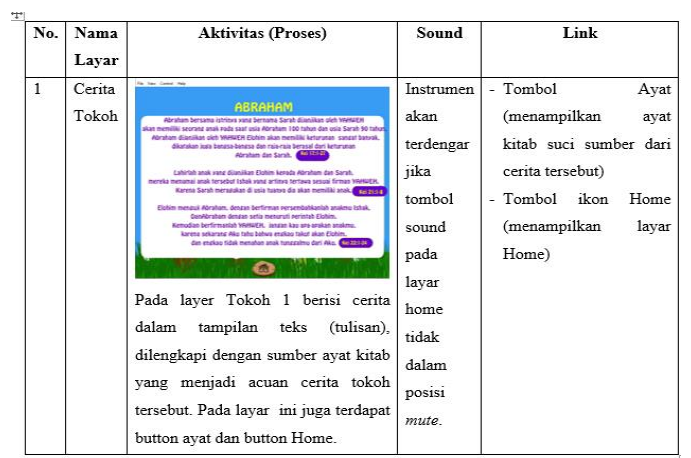

Gambar 6. Storyboard Tampilan Cerita Tokoh

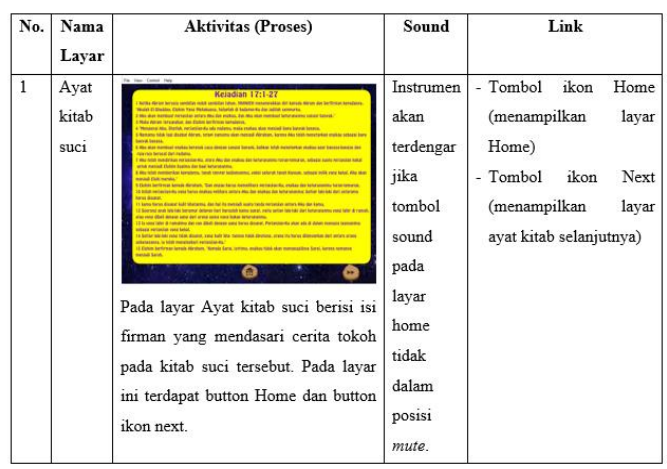

Gambar 7. Storyboard Tampilan Ayat Kitab Suci

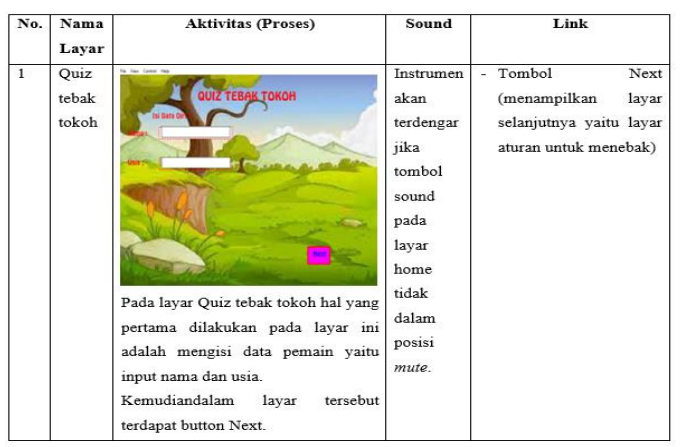

Gambar 8. Storyboard Tampilan Isi Data Pemain Quiz 


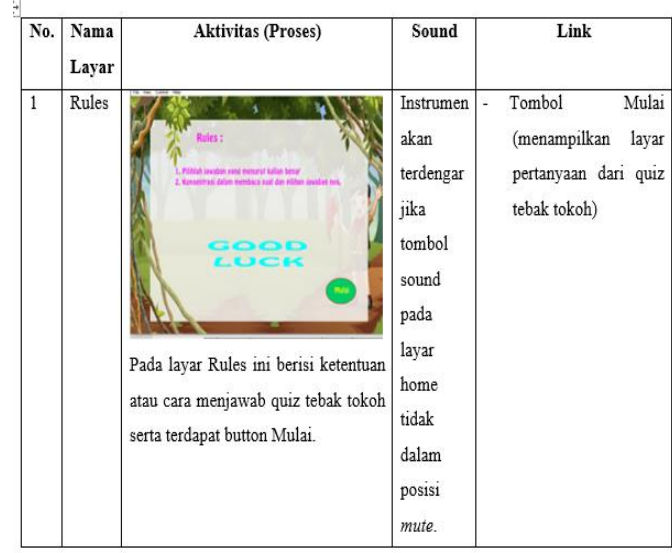

Gambar 9. Storyboard Tampilan Rules Quiz

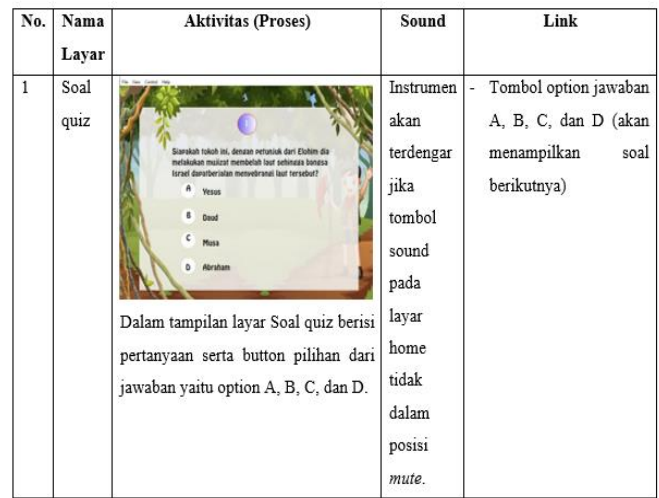

Gambar 10. Storyboard Tampilan Pertanyaan Quiz

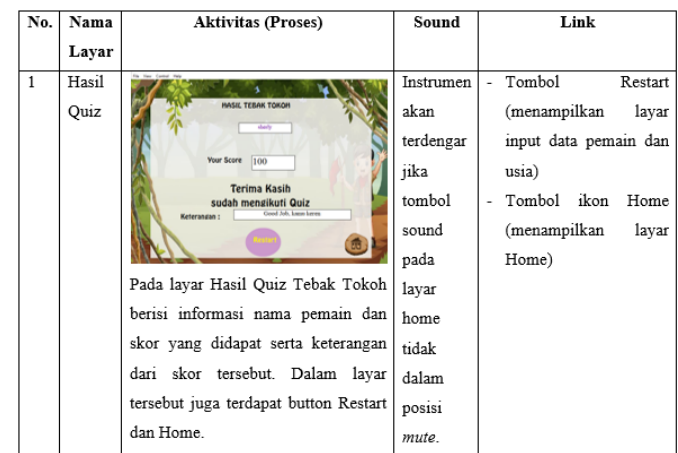

Gambar II. Storyboard Tampilan Hasil Skor Quiz

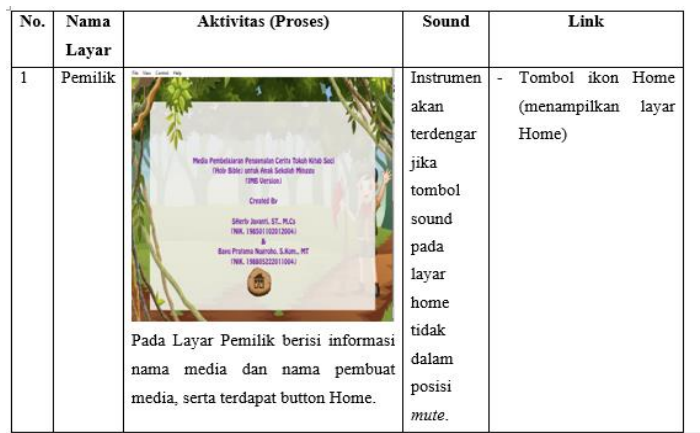

Gambar 12. Storyboard Tampilan Pemilik

c. Material collecting

Material collecting adalah tahap dimana pengumpulan bahan yang sesuai dengan kebutuhan dilakukan. Tahap ini dikerjakan paralel dengan tahap assembly. Bahan-bahan yang diperlukan dalam pembuatan aplikasi ini adalah sebagai berikut. Perangkat Keras (Hardware) yang dibutuhkan berupa datu unit Laptop, Perangkat lunak (Software) yang dibutuhkan yaitu; Windows 1064 bit, Adobe Macromedia Flash CS6, konversi file mp3 online, Paint 3D, gambar clip art, foto, animasi, audio dan lain-lain yang dapat diperoleh secara gratis lewat internet sesuai dengan kebutuhan rancangannya.

\section{d. Assembly}

Tahap assembly(pembuatan) adalah tahap dimana semua objek atau bahan multimedia dibuat. Pembuatan media didasarkan pada tahap design. Tahapan assembly ini meliputi, pembuatan marker, pembuatan konten motion, pembuatan background gambar 2D, dan pembuatan media. Pembuatan marker untuk konten 2D ini berbentuk silouete yang dibuat menggunakan Macromedia Adobe Flash CS6, menggunakan foto ikon tokoh, clip art atau gambar yang di dapat dari internet. Beberapa contoh marker dapat dilihat pada Gambar I3.

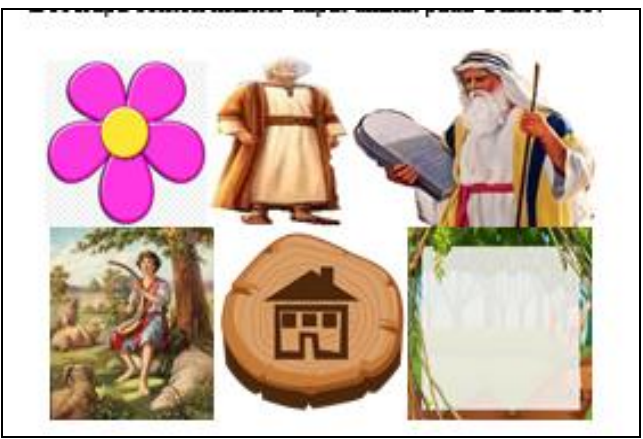

Gambar 13. Poto atau gambar clip art, ikon, background referensi pembuatan media

\section{e. Testing}

Tahap testing (pengujian) dilakukan setelah menyelesaikan tahap pembuatan (assembly) dengan menjalankan sistematau program dan melihat apakah ada kesalahan atau tidak. Pada pengujian fitur aplikasi, 
Sherly Jayanti \& Bayu Pratama Nugroho. Media Pembelajaran Cerita Tokoh Dalam Kitab 2021 Suci (Holy Bible) (Intuk Anak Sekolah Minggu Menggunakan Macromedia Flash

dan pengujian terhadap marker Pengujian fitur aplikasi ini merupakan pengujian terhadap fitur-fitur berupa tombol dan tampilan, apakah sudah berjalan sesuai yang diharapkan atau tidak. Pengujian media bisa dilihat pada Gambar 14 sampai dengan Gambar

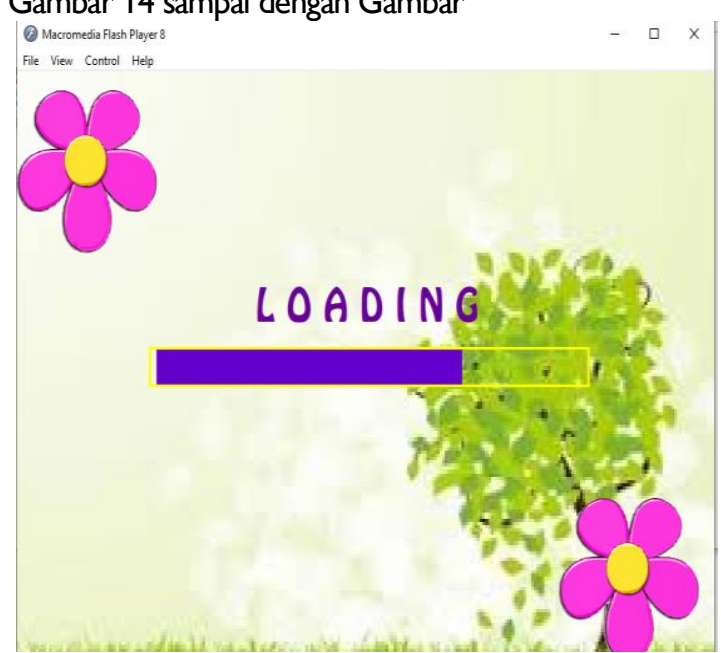

Gambar 14. Tampilan Saat Loading

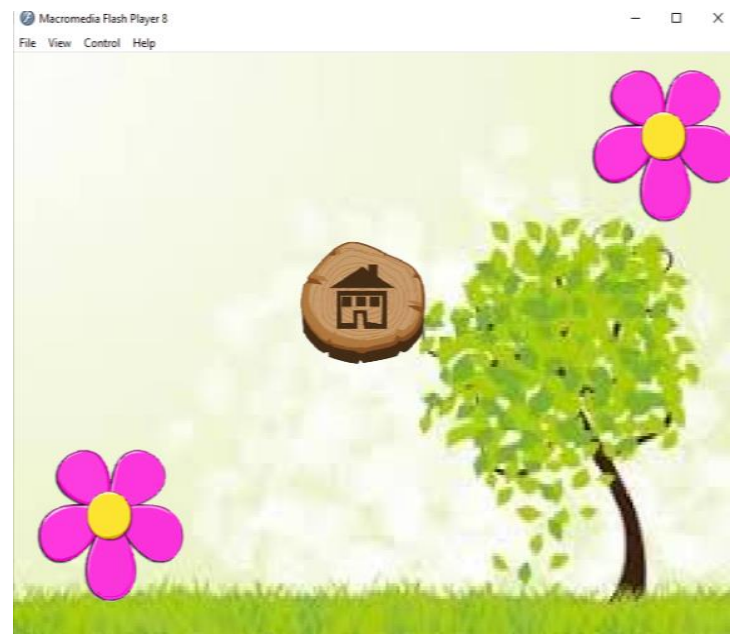

Gambar I5. Tampilan Tombol Home

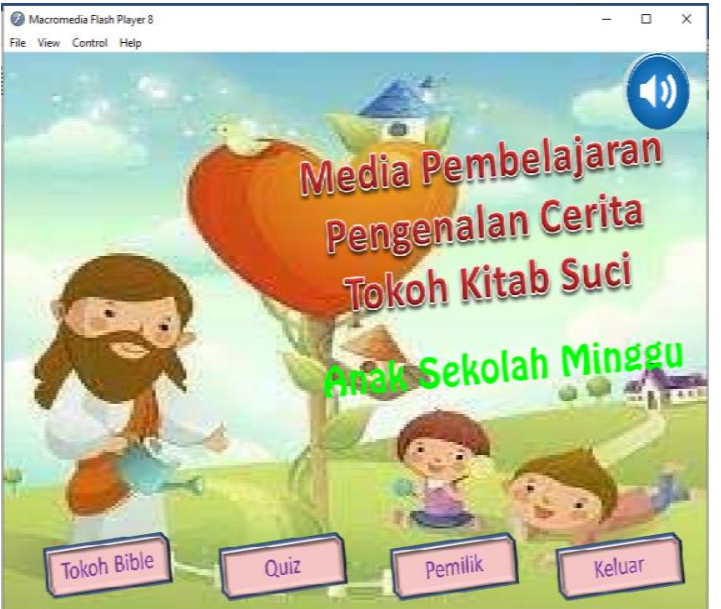

Gambar 16. Tampilan Home

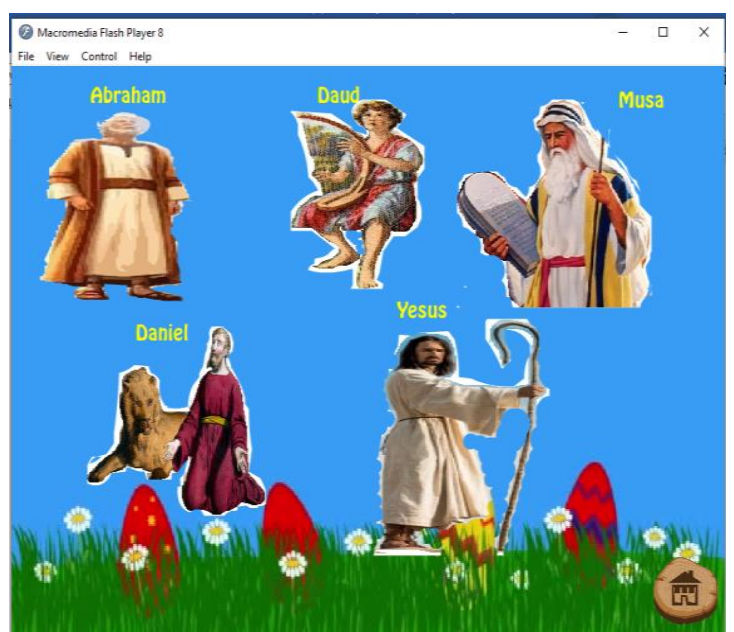

Gambar I7. Tampilan Menu Tokoh Kitab Suci

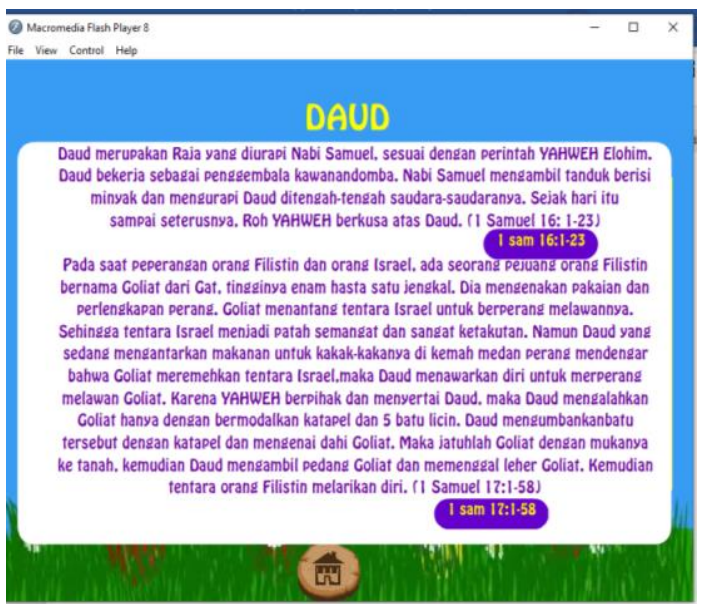

Gambar 18. Tampilan Cerita Tokoh 
Jurnal Sains Komputer dan Teknologi Informasi Page

e-issn: 2655-7460. Volume 4 No.1, November $2021 \quad 56-65$

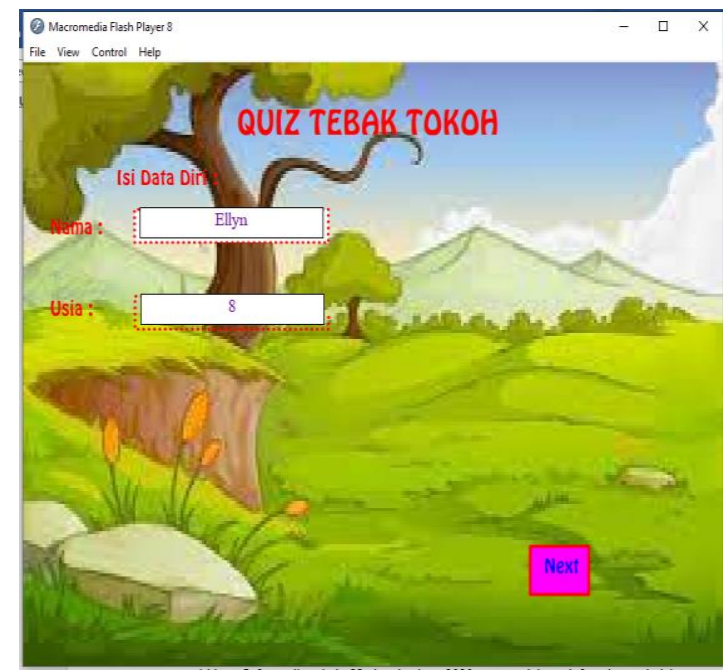

Gambar 19. Tampilan Input Data Pemain Quiz Tebak Tokoh

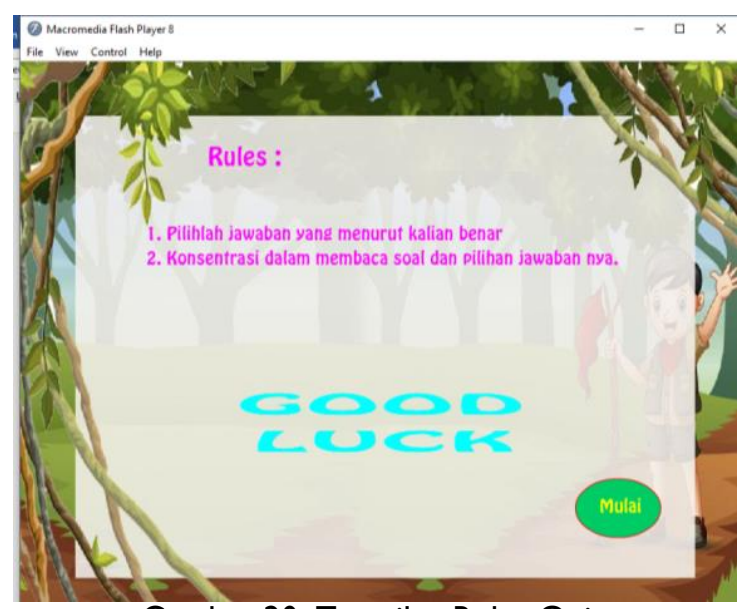

Gambar 20. Tampilan Rules Quiz

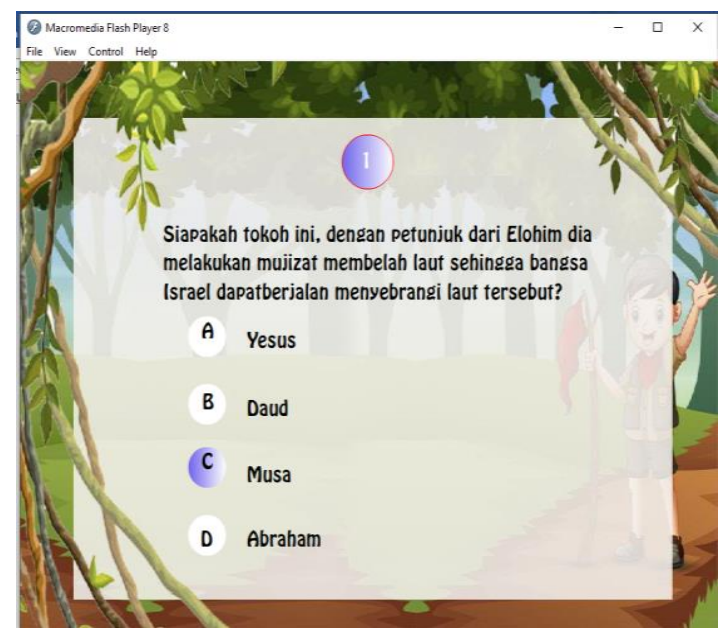

Gambar 2I. Tampilan Pertanyaan ke-I Quiz

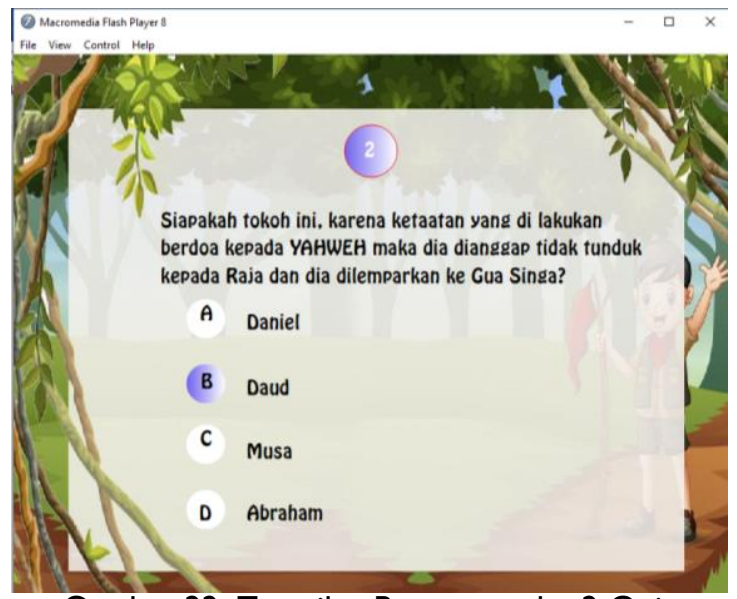

Gambar 22. Tampilan Pertanyaan ke-2 Quiz

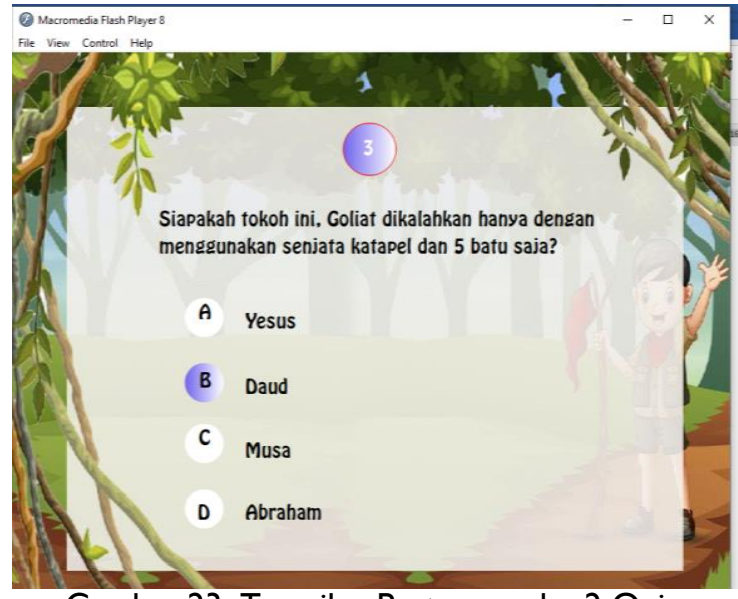

Gambar 23. Tampilan Pertanyaan ke-2 Quiz

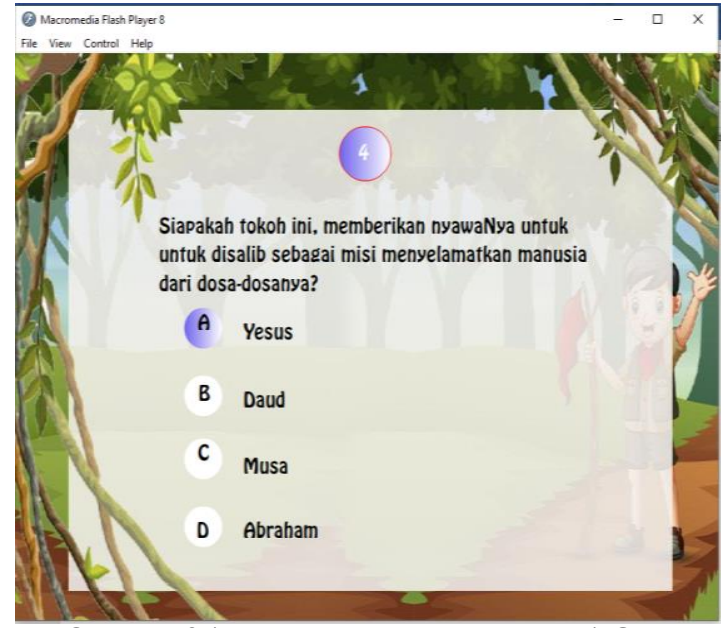

Gambar 24. Tampilan Pertanyaan ke-4 Quiz 
Sherly Jayanti \& Bayu Pratama Nugroho. Media Pembelajaran Cerita Tokoh Dalam Kitab 2021 Suci (Holy Bible) (Intuk Anak Sekolah Minggu Menggunakan Macromedia Flash

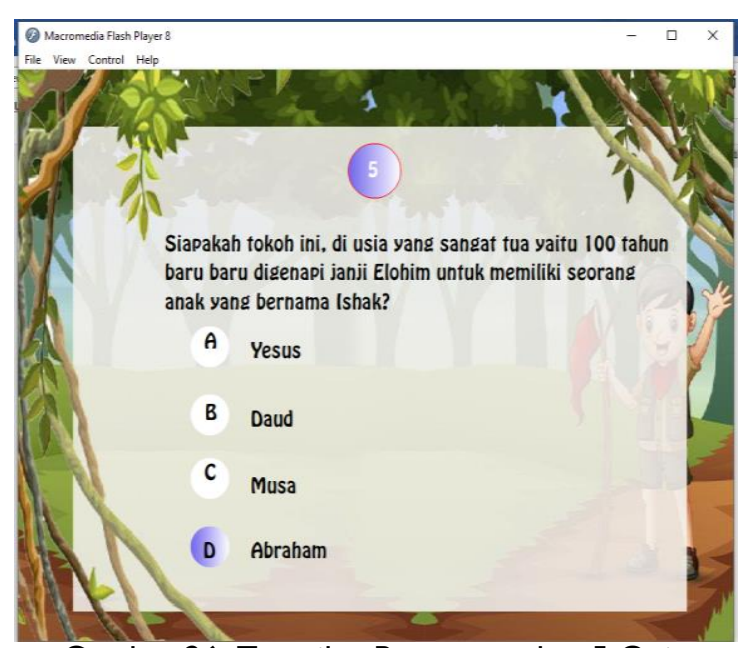

Gambar 26. Tampilan Pertanyaan ke -5 Quiz

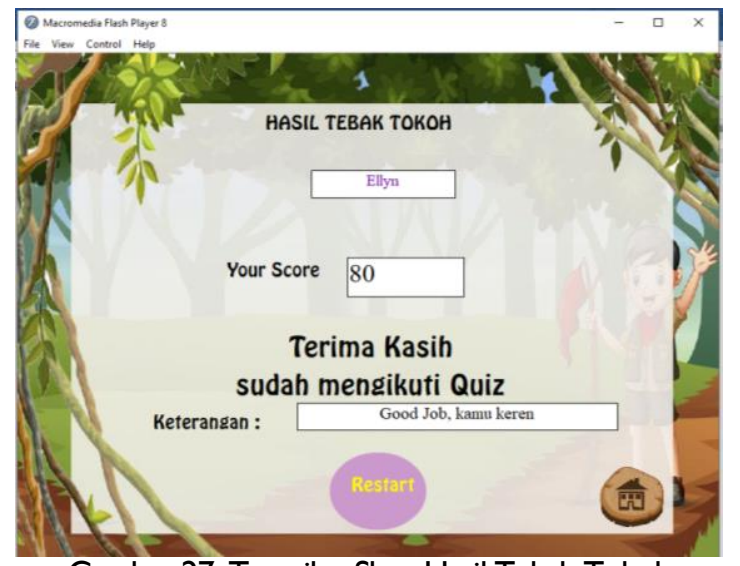

Gambar 27. Tampilan Skor Hasil Tebak Tokoh

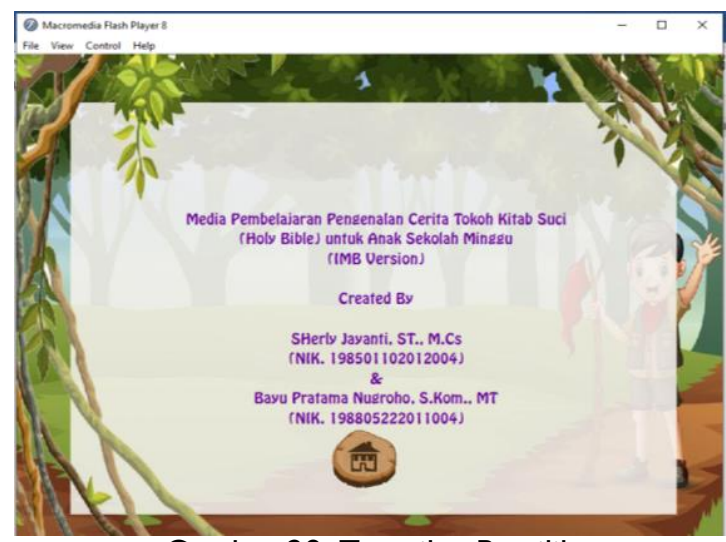

Gambar 28. Tampilan Pemilik

\section{f. Distribution}

Pada tahap ini, sistem yang akan disimpan dalam suatu media penyimpanan jika media penyimpan tidak cukup untuk menampung aplikasinya, kompresi terhadap sistem tersebut akan dilakukan. Untuk sementara format penyimpanan dalam format file *swf (flash movie) yang akan bisa dijalankan pada flatform pemutar video atau pun pada Macromedia flash Player.

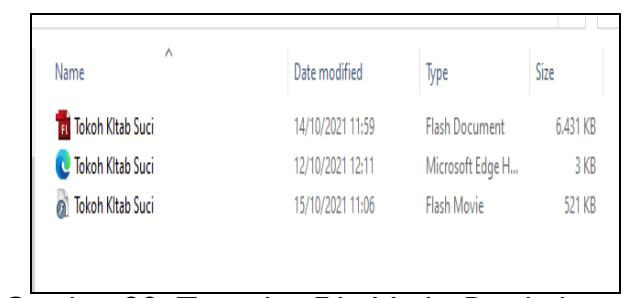

Gambar 29. Tampilan File Media Pembelajaran dengan format *SWF

\section{KESIMPULAN DAN SARAN}

\section{Kesimpulan}

Berdasarkan uraian dari masing-masing bab dan hasil pembahasan maka dapat disimpulkan bahwa pembuatan media pembelajaran pengenalan Alkitab berbasis multimedia sebagai berikut :

I. Untuk membangun sebuah media pembelajaran berbasis multimedia dapat menggunakan Macromediah Flash Professional CS6 sebagai alat bantu pembuatan.

2. Metode pengembangan MDLC (Multimedia Development Life (ycle) yang terdiri dari 6 tahapan, yaitu concept, design, material collecting, assembly, testing dan distribution merupakan metode yang cocok digunakan untuk pembuatan media pembelajaran berbasis multimedia.

3. Media pembelajaran pengenalan Tokoh Cerita Kitab Suci (Holy Bible) pada Anak-anak Sekolah Minggu dirasa lebih efektif dalam memperkenalkan cerita Tokoh Kitab Suci kepada anak-anak sekolah minggu. Dilengkapi dengan Quiz Tebak Tokoh serta ayat-yata Kitab suci sebagai referensi cerita tokoh tersebut.

\section{Saran}

Selama tahapan pengerjaan penelitian ini dapat diberikan saran sebagai berikut:

a. Diharapkan penelitian ini dapat dikembangan untuk menjadi sebuah media pembelajaran yang interaktif dan menampilkan banyak animasi sesuai dengan kebutuhan.

b. Dalam pengembangan media pembelajaran pengenalan tokoh cerita kitab suci selanjutnya agar bisa berbasis mobile sesuai kebutuhan dimasanya.

\section{DAFTAR PUSTAKA}

Arsyad, Azhar. (2016). Media Pembelajaran. Jakarta: Raja Grafindo Persada 


$$
\begin{array}{r|l}
\text { Jurnal Sains Komputer dan Teknologi Informasi } & \text { Page } \\
\text { e-issn: 2655-7460. Volume 4 No.1, November 2021 } & 56-65
\end{array}
$$

D. Diego Kasa. (20/5). Media Pembelajaran Pengenalan Alkitab Pada Anak-Anak Sekolah Minggu Berbasis Multimedia (Studi Kasus Pada Gereja Anugerah Samarinda). wicida repository is powered by EPrints 3 which is developed by the School of Electronics and Computer Science at the University of Southampton. Retrieved from: http://repository.wicida.ac.id/536/

Isriani Hardini dan Dewi Puspitasari. (20/2). Strategi Pembelajaran Tepadu.Yogyakarta: FAMILIA.

Jogiyanto, H. 2010. Analisis dan Desain Sistem Informasi, Edisi IV. Jogyakarta: ANDI

Kendall, K.E. dan Julie, E.K., 20I I, Systems Analysis and Design, Prentice Hall, New Jersey

Musfiqon. 2012, Pengembangan Media dan Sumber Media Pembelajaran. Jakarta : PT. Prestasi Pustakaraya.

N. Nurcikawati, dkk. (20/8). Rancang Bangun Media Pembelajaran Trigonometri Berbasis Multimedia Interkatif. Jurnal LP3M Universitas Sarjanawijaya Tamansiswa Yogyakarta. Vol.4 No. 2. II4-I2I.

R. Rahmat \& Irfan, D. (20/9). Rancang Bangun Media Pemebelajaran Pembelajaran Komputer dan Jaringan Dasar di SMK. Jurnal Vocational Teknik Elektro Dan Informatika, Vol. 7 No. I, 48-53. Retrieved from:

http://ejournal.unp.ac.id/index.php/voteknika larticle/view/I03642/101428

Sudjana, N, Rivai, A. (2015). Media Pengajaran. Bandung: Sinar Baru Algensindo.

S. Valentine Grieda, dk. (20/6). Pembuatan Aplikasi Media Interaktif Untuk Pengenalan Tokoh Alkitab Berbasis Android. Jurnal Infra Petra Christian University. Publish 2016. Retrieved from : https://www.neliti.com/publications/I0320I/ pembuatan-aplikasi-media-interaktif-untukpengenalan-tokoh-alkitab-berbasis-andr

https://kbbi.web.id/kitab (diakses : Sabtu, 07-03202I. Pukul .09.00wib). https://kbbi.web.id/tokoh (diakses : Sabtu, 06-03202I. Pukul .I3.00wib).

https://www.yhschurch.com/resources/imb/ (diakses : Sabtu, 06-03-202I. Pukul .I3.20wib).

https://kbbi.web.id/cerita (diakses : Sabtu, 06-032021. Pukul .I3.30wib).

Link untuk ikon dan gambar (diakses : Selasa, 0510202I. Pukul I0.23wib):

https:/www.abbaloveministries.org/abrahammenjadi-bapa-banyak-bangsa-karena-iman/

http://litera.id/2018// 0/27/cerita-cerita-darisekolah-minggu/

https://musicstax.com/playlist/ibadah-anak-sekolahmingguterlengkap/4QNPMaHHrPy6ZOKaEFmeQ D

https://rubrikkristen.com/I2-pahlawan-iman-dalamibrani-I I/

https://rubrikkristen.com/7-fakta-penting-tentangmusa-menurut-alkitab/

https:/www.papamamagroup.com/2018/05/kesuka an-raja-daud.html

https://studibiblika.id/2019/08//3/khotbah-dan-6pelajaran-dari-daniel/

https://id.depositphotos.com/stockphotos/percayalah-yesus.html

https://kartunhd.blogspot.com/2020/03/terbagus30-gambar-kartun-rumput.html

https://godean.web.id/2021/06/unduh-gampang-72kumpulan-background-rumput-animasikeren.html

Link audio untuk Button dan Instrumen (diakses : kamis, 07-I0-202I):

https://www.soundeffectsplus.com/product/correct -answer-bell-and-applause-02/

https://soundscrate.com/animated.html https://soundscrate.com/feel-good-music.html 